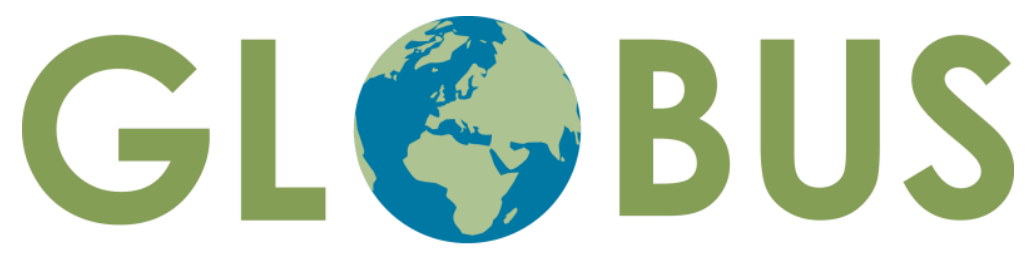

Reconsidering European Contributions to Global Justice

\title{
On Protection and Justice The Proposals for Reform of the Common European Asylum System
}

Michela Ceccorulli

\section{GLOBUS Research Papers}

4/2018 - March 2018 
Michela Ceccorulli

On Protection and Justice: The Proposals for Reform of the Common European Asylum System

GLOBUS Research Paper 4/2018

March 2018

(C) Michela Ceccorulli

GLOBUS Research Papers (online) | ISSN: 2535-2504

http://www.globus.uio.no/publications/globus-research-papers/

Michela Ceccorulli is Research Fellow at the University of Bologna

Reconsidering European Contributions to Global Justice (GLOBUS) is a research project that critically examines the EU's contribution to global justice.

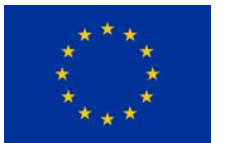

Funded by the European Union's Horizon 2020 programme. This work is the sole responsibility of the author. It does not reflect the opinion of the EU. The Research Executive Agency is not responsible for any use that may be made of the information it contains.

\section{www.globus.uio.no}

E Twitter:@globus_h2020

f Facebook:@globus.h2020

Issued by:

ARENA Centre for European Studies

University of Oslo

P.O. Box 1143 Blindern

0318 Oslo, Norway

www.arena.uio.no

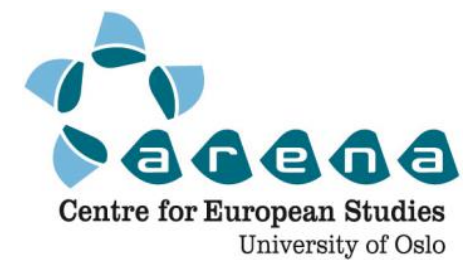




\section{Abstract}

The reform of the Common European Asylum System (CEAS) was much wished for both by committed Europeans and by human rights advocates more generally. Ideally, the European Union (EU) would have developed a single asylum system with equal criteria applying to all Member States and full recognition of the international protection status everywhere in the Union. This would have taken care of the primary concern of the Member States, that is, the prevention of asylum seekers' secondary movements. The abandonment of the nation-specific prerogatives would also have allowed for a focus on the asylum seekers' needs. However, the proposals issued by the European Commission between 2015 and 2016 in no way suggest that a uniform asylum system is on the way. This paper examines the implications of some of these proposals for the governance of asylum and for the understanding of international protection as the guarantee of specific rights to foreign citizens in need. It further assesses the proposals with respect to different conceptions of global political justice. The justice conceptions of non-domination, impartiality and mutual recognition as developed in the GLOBUS project are particularly useful in both uncovering the competing reasons behind the specific direction of the proposals for reforms, and in assessing their implications.

\section{Keywords}

Asylum, European Union, international protection, secondary movements

Research for this paper has received funding from the European Union's Horizon 2020 research and innovation programme under grant agreement no. 693609 (GLOBUS). 



\section{Introduction ${ }^{1}$}

Between 2015 and 2016 the European Commission issued a package of proposals for the reform of the Common European Asylum System (CEAS). ${ }^{2}$ These proposals responded to the need for more standardization among Member States' asylum systems; standardisation had been set as a long-term objective back in the 1990s, when the first steps towards a harmonised asylum system were taken. A closer approximation of Member States' asylum systems was functional to preservation of the internal free movement space from disruptions (Pastore 2017: 12; Balleix 2017). In fact, it would

${ }^{1}$ This work is part of the GLOBUS project's Work Package 3 'Migration and global justice' led by the University of Bologna. The author is extremely grateful to Dr. Salvatore Fachile and Dr. Nazzarena Zorzella of the Association for Juridical Studies on Immigration and to Prof. Marco Balboni of the University of Bologna, Department of Social and Political Sciences for their valuable and informed insights on the asylum domain. I am indebted to Prof. Sonia Lucarelli and Enrico Fassi for stimulating discussions and thoughts on the topic. I am also grateful to Helene Sjursen, Erik O. Eriksen, Kjartan Koch Mikalsen, Espen D. H. Olsen and other colleagues from ARENA for precious comments on this work. Last, but not least, I have benefitted from discussions at seminars organized at the University of Bologna with, among others, Sonia Lucarelli, Marco Borraccetti, Cinzia Bevitori, Enrico Fassi, Giorgio Grappi, Agustín José Menéndez, Sandro Mezzadra, Antonio Zotti, Ayhan Kaya, Pierluigi Musarò, Ferruccio Pastore, and Elly Schlein. Of course, the usual disclaimer applies.

${ }_{2}^{2}$ Proposal for a Regulation of the European Parliament and of the Council establishing a common procedure for international protection in the Union and repealing Directive 2013/32/EU (COM(2016) 467); Proposal for a Regulation of the European Parliament and of the Council on standards for the qualification of third-country nationals or stateless persons as beneficiaries of international protection, for a uniform status for refugees or for persons eligible for subsidiary protection and for the content of the protection granted and amending Council Directive $2003 / 109 /$ EC of 25 November 2003 concerning the status of third-country nationals who are longterm residents (COM(2016) 466); Proposal for a Directive of the European Parliament and of the Council laying down standards for the reception of applicants for international protection (recast) (COM(2016) 465); Proposal for a Regulation of the European Parliament and of the Council establishing a Union Resettlement Framework and amending Regulation (EU) No 516/2014 of the European Parliament and the Council (COM(2016) 468); Proposal for a Regulation of the European Parliament and of the Council establishing the criteria and mechanisms for determining the Member State responsible for examining an application for international protection lodged in one of the Member States by a third-country national or a stateless person (recast) (COM(2016) 270); Proposal for a Regulation of the European Parliament and of the Council on the establishment of 'Eurodac' for the comparison of fingerprints for the effective application of [Regulation (EU) No 604/2013 establishing the criteria and mechanisms for determining the Member State responsible for examining an application for international protection lodged in one of the Member States by a thirdcountry national or a stateless person], for identifying an illegally staying third-country national or stateless person and on requests for the comparison with Eurodac data by Member States' law enforcement authorities and Europol for law enforcement purposes (recast) (COM(2016) 272); Proposal for a Regulation of the European Parliament and of the Council on the European Union Agency for Asylum and repealing Regulation (EU) No 439/2010 (COM(2016) 271); Proposal for a regulation of the European Parliament and of the Council establishing an EU common list of safe countries of origin for the purposes of Directive 2013/32/EU of the European Parliament and of the Council on common procedures for granting and withdrawing international protection, and amending Directive 2013/32/EU (COM(2015) 452). 
restrict the space for secondary movements of asylum seekers, that is, the unauthorised movement of asylum seekers from one Member State to the other, a key priority for the European Union (EU). In addition, the EU had expressed an increasing commitment to the creation of a truly unique asylum system, with equal criteria applying to Member States and full recognition of international protection everywhere in the Union. Ultimately, this objective would have contributed not only to solve secondary movements' issues; but also to reduce asylum imbalances among the Member States; to create a protection space with full enjoyment of rights; and to strengthen the EU's credibility on human rights support, matching deeds with rhetoric.

The attempt to improve European performance on human rights' treatment in the field of asylum was clearly recorded in the Regulations and Directives passed between 2011 and 2013. This was mainly due to the entry into force of the Lisbon Treaty, to the legal relevance acquired by the Charter of Fundamental Rights and to the EU's attempt to respond to harsh criticism against the first provisions on asylum, which were approved some years earlier (2003-2005). It was the same Commission to acknowledge vagueness of some of the concepts and the optional nature of some of the provisions which did not lead to similar identification, recognition and receptions conditions. She was seemingly able to recognise that incomplete or incorrect transposition was contributing to uneven standards among the Member States, towards, most of the time, lower protection levels than those expected (European Commission 2013: 16). Hence, the recast Directives delivered then had explicit objectives regarding both reducing discrepancies among the Member States and improving the protection standards (European Parliament and Council 2011).

However, amid the Member States' different positions, the 2015-2016 proposals are in no way likely to approach both the aim of a unique asylum system and that of an effective protection space for asylum seekers. If most of the existing Directives will convert into Regulations binding in their entirety and immediately applicable to the Member States (with the notable exception of the one on reception conditions), the standardisation proposed is one flattened on the main objective to avoid secondary movements of asylum seekers in a system where protection determination, recognition and implementation is still limited to the national level. However, if the objective to end secondary movements is not achieved through the creation of a uniform and asylum system, some actors would be called to accomplish this task more than others. Moreover, if states' prerogatives and national criteria trump asylum seekers' rights, the same understanding of protection as focused on asylum seekers' needs is to be impacted. How this all fares in terms of justice?

Providing a justice assessment of the domain of asylum is fundamental both to test the EU's coherence with respect to its purported human rights' rhetoric and to evaluate the EU's justice advancement in the issue of international protection increasingly discussed at the global level (Sjursen 2017; Grandi 2016; Pascouau 2017). A 'taste of justice' recently advanced by the EU has been provided through the management of the massive arrivals of asylum seekers since 2015 on the EU's shores. Ultimately, it can be 
inferred that the refugee crisis, as it has been called by the Union, has also surreptitiously impacted the drafting of the proposals for reform of the asylum system: more than ever before the Member States' distant views on the issue of asylum have been made clear; lack of solidarity has been evident, and disregarding of asylum seekers' rights and faiths widely denounced. Of particular interest, the management of the refugee crisis has emphasised further the objective to prevent asylum seekers' secondary movements to ward off the possible collapse of the Schengen system, severely threatened by the progressive uncoordinated re-introduction of border checks among some of the Member States between 2015 and 2016.

In its analysis of the 'justice' impact of some of the provisions of the proposals for reform of the CEAS, this paper uses the justice conceptions adopted by the GLOBUS project (non-domination, impartiality, and mutual recognition). As a matter of fact, variegated and yet fully reasonable as they are, the three justice conceptions are of particular help in assessing the EU's proposals, in identifying the direction the EU's asylum policy is taking and ultimately in providing an explanation of why the EU has proposed such a conduct. This is so because asylum is the area of closest intersection among the three justice perspectives: (i) it touches upon states' prerogatives over the control of their borders and attribution of rights and duties with their constituencies, recalling a justice conception as non-domination; (ii) it is closely bound up with basic human rights, supporting a justice conception of impartiality; and (iii) the international asylum conventions requires an evaluation ad personam of applications, hence imposing specific attention to the applicant's subjective conditions, consolidating a justice conception as mutual recognition. The coexistence and simultaneous advancement of these justice conceptions is not always easily solved; analysing how they figure in the Commission's proposals is hence interesting to then assess the dilemma attaining the Union and ultimately the priority given to one or the other.

A clarification concerning the object of investigation is necessary: although the package of proposals will be subject to further rounds of negotiations, analysis of the Commission's proposals content is still relevant because it provides insights into some enduring features of the asylum policy, of new directions pursued by the EU, and of the normative challenges to which these insights give rise.

The study develops as follows: the first section introduces the three understandings of justice as endorsed by the GLOBUS project and their declination in terms of migration. The second and third sections evaluate some of the potential drawbacks of the proposals for reform with a view to the conceptions of justice taken into consideration. ${ }^{3}$ Specifically, section two considers the effects on some of the actors involved in the governance of asylum, while section three considers the impact that the proposals may have on the overall meaning of international protection in the EU. The fourth section briefly concludes.

\footnotetext{
3 Here a methodological note is required: the analysis of the proposals for reform takes into account all previous Directives and Regulations delivered in the realm of asylum and considers both changes in the rhetoric used and in the provisions advanced. In doing that, this work draws on Ceccorulli 2017.
} 


\section{Justice and asylum: the need for effective assessment criteria}

Asylum has been quite widely debated in the realm of political theory (Carens 2013; Miller 2015, 2016; Gibney 2004, 2015 among others). Some scholars would agree that asylum seekers deserve special protection as victims of human rights abuses, but the responsibilities for them may differ according to the physical presence (or not) of the protection seekers in the national territory, a condition particularly important for the proponents of the so-called 'communitarian approaches' (Miller 2015). For scholars at the opposite end of the spectrum, not only refugees, but migrants in general qualify as rightful claimants of inalienable and fundamental rights which trump sovereignty claims (Carens 2013). For all their intellectual sophistication, these debates are likely to neglect a reality which involves more complex dilemmas than that of keeping borders open or closed. In particular, how is it possible to reconcile the widespread consensus on the need for protection of an increasing number of persons (endorsed by the EU) with scant legal responsibilities delineated at the international level? Or, and more in tune with our research question, what if 'the community' and 'human beings' represent only two of the possible coexisting concerns in certain political entities, such as the EU?

Eriksen (2016: 2) rightly notes that the European Union represents a step beyond Westphalian intergovernmentalism: 'from its very inception it has proclaimed an ambition to promote justice at global level', but specifically because of its distinctive nature it may find it hard to cope with the claims of its multiple audiences (the Member States, the European community and asylum seekers). Hence, the form and content that justice may assume in the field of asylum, result from a trade-off among different claims. It is for this reason that adopting Eriksen's (2016) three conceptions, which may exist simultaneously, seems a promising analytical choice: all of them are able to catch a part of the justice conception advanced by the EU. At the same time, their insistence on specific claims allows grasping the priorities attached as well as the justice conceptions obscured or even violated.

'Non-domination' refers to a situation of non-subjugation, control or interference of an actor by any other actor. According to a conception of justice as non-domination, the integrity and sovereignty of states are respected together with their system of protecting rights (Eriksen 2016, p. 11). Applied to migration, non-domination is understood in relation to state-like entities or political actors such as the EU, its Member States and third countries. It presupposes the absence of 'arbitrary interference' and fair and equally participated relations (Fassi and Lucarelli 2017: 3-4). Contrary to non-domination, impartiality is closely related to the concept of non-discrimination, of equal basic rights and liberties (Eriksen 2016: 14) and of human dignity (Eriksen 2016: 15) and it mostly refers to individuals, who are the ultimate units of moral concern (Eriksen 2016: 14). As applied to the field of migration, justice as impartiality requires the acceptable treatment of migrants and asylum seekers according to leading international (and EU) laws and conventions; nondiscrimination in terms of basic rights with respect to EU or Member State nationals; 
and the equal treatment of persons in need of protection. Finally, mutual recognition as a justice conception recognises the importance of each subject's (individual, group or polity) voice being heard and of active participation in a governance process of which that subject is a part. As noted by Eriksen, having a say in a reason-given process is crucial for a definition of justice understood as 'mutual recognition' which envisages due hearing, respect for individual identity and of the practices and activities that are valued, of belonging and difference (Eriksen 2016: 19-20). In the case of migration, mutual recognition implies not only taking into account the personal stories of the persons concerned and their vulnerable statuses 4 , but also allowing them a voice in the governance of migration.

The three justice conceptions just outlined are hence of interest for the analysis of the proposals for reform of the Common European Asylum System, which is assessed below with respect to the governance of the phenomenon (and to the actors taking a part in it) and to the understanding of international protection in the EU.

\section{The impact of the proposals for reform on the actors involved in the governance of asylum}

All the proposals for reform issued by the European Commission between 2015 and 2016 underlined the main objective of ending 'secondary movements' in the EU. The proposal for Regulation on standards for qualification of third country nationals or stateless persons as beneficiaries of international protection, for example, maintained that the intent to harmonise Member States' legislations more thoroughly was mainly due to the persistence of uneven standards among the Member States: 'These divergences', the Commission stated, 'contribute to secondary movements and asylum shopping, create pull factors and ultimately lead to an uneven distribution among the Member States of the responsibility to offer protection to those in need' (European Commission 2016a: 2). Concrete proposals concerning harmonisation would, for example, include the removal of 'optional clauses' and their transformation into binding provisions. However, some of the new measures would strongly impact on the domestic legislation of some Member States in a way that might run contrary to their ongoing protection system. Of interest is the obligation to verify 'internal protection' options, understood as the possibility to receive protection in another part of the origin country (which would render the request for protection within the European Union pointless) (European Commission 2016a, Art. 8 (1)). A similar effect applies in the case of the possible adoption of a common EU list of safe countries of origin and of the obligation to issue equally lasting residence permits in the Member States, discriminating, however, between refugee and subsidiary protection status (respectively three years and one year). The issue is not procedural: the common standards proposed in

\footnotetext{
4 For an overview on the concept and practice of vulnerability and vulnerability protection in the EU see Del Gaudio et al. 2016.
} 
the Regulation would apply equally to all Member States, and the decision-making procedure is not arbitrary either. 5 The issue, though, is problematic for our conceptions of justice when Member States are forced to downgrade their protection systems (ECRE 2016b: 2). In Italy, for example, where the 'right of asylum' (diritto di asilo) is enshrined in the Constitution (Art. 10) and is quite extensive (at least as elaborated in the Constitutional dictate), the decision has been deliberately taken never to adopt the 'internal protection clause' and a list of safe countries, while residence permits for refugee status and subsidiary protection last five years each. Downgrading the protection system does not necessarily qualify as a violation of human rights; clearly, though, the proposed standardisation is not one calibrated on the highest protection standards present in the Member States.

Another interesting finding of the analysis of the proposals, concerns the allocation of responsibilities for the examination of asylum requests in the European Union, i.e. the Dublin system (European Commission 2016b). The Dublin system is the cornerstone of the entire asylum policy in the European Union. Framed from the outset as a Regulation, Dublin has propounded the idea that asylum in the European Union is a 'system to be governed' with specific rules for Member States. This aim was strictly related to the proper functioning of the Schengen 'free border' control system, which may have allowed multiple applications ('asylum shopping') or disproportionate applications to most welcoming systems (secondary movements). To help towards achieving this 'allocation of responsibility' objective, a system for the comparison of fingerprint data was established in 2000 - the European Dactyloscopy (EURODAC). The overall functioning of the Dublin system has been severely impaired by the huge inflows of recent years, in so far as frontier states such as Italy and Greece, generally responsible for the examination of asylum applications as 'first entry states', have not been able to fulfil their obligations properly because they have been overwhelmed by massive arrivals. The disproportionate burden on frontier states, however, fits awkwardly with Article 80 of the Treaty on the Functioning of the European Union, which explicitly evokes 'solidarity and fair sharing of responsibilities' as guiding principles in the EU's action. The insertion of a 'corrective mechanism' in the proposal for revision of the Dublin system has been specifically motivated by the European Commission 'to ensure a fair sharing of responsibility between Member States' and to 'mitigate any significant disproportionality in the share of asylum applications between Member States resulting from the application of the responsibility criteria' (European Commission 2016b: 17-18). But some other measures proposed in the reform seem still to impose a heavy burden on frontier states.

\footnotetext{
5 The recast proposal on reception (European Commission 2016c) remains in the form of a Directive. This is important to emphasize, given that a thorough standardization of measures among Member States would have contributed to downscaling secondary movements. Discretion allowed in reception has sometimes induced disputable practices with respect to asylum seekers (detention for example) on moral and legal grounds (see Ceccorulli 2017).
} 
From a justice point of view the Dublin Regulation seems to raise an issue of 'structural injustice', where structural problems inherent in the way in which the Regulation has been framed bring about 'uneven distributive effects' (Eriksen 2017). This peculiar injustice is hardly attributable to specific actors: the context in which it operates may have changed significantly since the establishment of that political-legal provision; or external factors may have produced a significant change in the way the measure affects the parties to it. That is, causality, and hence moral responsibility, cannot be effectively assessed. However, political obligations are owed among the equal members of such institution, first and foremost that of solidarity, that is, that to collectively redress injustice (Eriksen 2017: 12). When the Dublin Regulation was established, solidarity was not upfront (Guild et al. 2015). But the EU was not even supposed to have to cope with the scale and nature of ongoing problems: inflows to the European Union were quite modest; legal channels of entry and arrivals by air predominated. In a context which exhibits significant divergences with respect to the past, many commentators have argued for a complete overhaul or even the elimination of the Dublin Regulation. However, the proposal for revision of the Dublin Regulation is not brave enough in this sense (ECRE 2016c; European Parliament 2017). ${ }^{6}$

Three proposed measures are of relevance here: first, some deadlines whose expiration implied a shift of responsibility between Member States have been deleted, such as the 12-month responsibility clause from irregular entry, which put a clear burden on frontier states (European Commission 2016b, Art. 15). The elimination of that deadline would impose a permanent responsibility upon those states. Second, the proposal to introduce the obligation for the Member State of application (the first state of entry, Art. 4) to check whether (i) the application is admissible (the applicant has not transited through a first country of asylum or has no relation with a safe third country); (ii) that it is founded (the applicant does not come from a safe country of origin); and (iii) that the applicant does not constitute a security risk (European Commission 2016b: 15). In fact, the Commission argues, this would help prevent applicants with such claims or representing security threats being 'transferred among the Member States' (European Commission 2016b: 24). And third, the fact that the 'collective allocation mechanism' (the corrective mechanism) proposed would be triggered before the Dublin check but after the 'admissibility check' (that is, after a first screening of applications is made according to the 'safe countries' criteria and security concerns) (European Commission 2016b: 18; ECRE 2016d)7. If this is mostly explained by the aim to avoid secondary

\footnotetext{
${ }^{6}$ A true paradox emerges, for example, from the parallel implementation of the EU Relocation decisions of 2015 aimed at alleviating pressures upon frontier States (which foresees the departure of asylum seekers for other member States) and the implementation of returns of asylum seekers to the frontier State according to the Dublin Regulation. As observed by AIDA, it may well be the case (as in that of Italy) that returns outnumber departures, generating a real 'solidarity-responsibility conundrum' (AIDA 2017: 5).

7 According to ECRE, this assessment of inadmissibility or of the existence of conditions leading to accelerated procedures prior to Dublin evaluation would also contravene the EU's objective to keep families united, a right expressed in the Charter of Fundamental Rights of the European Union (ECRE 2016d).
} 
movements, according to some commentators, these measures may turn frontier states into 'big hotspots', with burdens difficult to sustain. Every 'corrective mechanism', it has been maintained, would intervene too late in already collapsing frontier states (Schlein 2017).

The scope of the proposals for reform of the asylum system in the European Union extends far beyond Member States' relations. In fact, it impacts also on the third countries (Triandafyllidou 2017). This is a further reason why considering how the EU accommodates 'internally' (how ready it is to share responsibility and make the internal management of asylum feasible) is necessary for understanding and evaluating relations with third states. The external dimension of asylum is not a new issue; instead, the EU has, time and again, reasoned on the protection opportunities outside the EU. The new package of proposals for revision of the asylum system is promoting concrete steps forward in this regard. It does so by effectively creating the bases of a 'bridge' between the internal and external dimensions of asylum.

Concepts such as 'safe country of origin', 'first country of asylum', and 'safe third country'9 are not new in the legislation on asylum. Already in 2005, the first Directive on Procedures (European Council 2005) cited the three concepts as coherent with the aim of speeding up the process of application examination. The rationale was that a request for asylum would prove unfounded in the case of countries of origin identified as 'safe'. In the other two cases, instead, there would be no point in requesting asylum specifically in the EU, for the applicant would be able to receive a form of protection in a third country; whence derives the 'inadmissibility' of the request. Ultimately, according to the Commission, focusing on 'true needs' would save time and resources (European Commission 2003: 8). However, before the 2016 proposal for a Regulation establishing a common procedure for international protection in the European Union (European Commission 2016d), reliance on these concepts to apply specific procedural rules (such as the accelerated and border procedures) and to avoid 'entering into the merits' of the asylum request was merely an 'option' (European Commission 2016d, Art. 36; European Commission 2015b: 2). And many Member States had always refused to adopt any 'list' of safe countries. By contrast, the new proposal makes it mandatory for Member States to assess 'unfounded' or 'inadmissible' asylum requests. An effective means to implement these concepts would be the European Union Asylum Agency (European Commission 2016e) proposed as an upgrade of the existing European Asylum Support Office, established in 2010 (European Parliament and European Council 2010). If the Office was already intended to have a role in the 'external dimension' of asylum (European Parliament and European Council 2010: 6),

\footnotetext{
${ }^{8}$ Address by Loredana di Leo to the Conference 'Fortress Europe: towards the containment of inflows and new restrictions to the right of asylum', Association for Juridical Studies on Immigration, Milan, 20 March 2017.

9 'Safe countries of origin' are considered safe on the basis of criteria specified in the Procedure Directive. Their citizens are therefore clearly not in need of international protection. A 'first country of asylum' is a country where an asylum seeker has already enjoyed protection and where s/he can again receive such protection. Finally, a 'safe third country' is one which fulfils criteria attesting to its protection capabilities and can therefore examine asylum applications.
} 
the new Agency would see its task expanded. The proposal is the creation of an independent centre of expertise (European Commission 2016e: 2) furnishing information on countries of origin, assessing 'safe countries of origin', and evaluating the situation in third countries to be considered as potentially ‘safe' (European Commission 2016e, Art. 11).

If the abovementioned proposals seem to rely increasingly on third countries, what are their implications from a justice point of view? Is the EU limiting these countries' choice situation (Mikalsen 2017)? It is still too early to tell, but we already have an example of how the 'safe countries' concepts may operate in the governance of asylum. Third states (often heavily pressured by inflows themselves) may be further impacted by the EU's decisions, as they will see the number of persons in their countries rising as a result of others' decision. And their acceptance to be part of EU's migration governance is likely to depend on the expected benefit that they hope to gain from the EU, whose general (and in particular financial) support is crucial to them most of the time. Inevitably, this would feed the debate of 'conditionality', whereby third states would see their capability to make their own choices reduced (a domination effect, hence). Also, more subtle forms of domination may be at work: it would be the EU (and namely the European Union Asylum Agency) ${ }^{10}$, for example, that decides which country qualifies as a safe country according to its own criteria and the countries that may be added to the list (depending inter alia on discretional elements, such as the amount of applications for international protection received in the EU). However, the high stake the EU puts on the reduction of irregular inflows may represent itself a powerful card in the hand of third states. The EU-Turkey Statement of March $2016^{11}$ is particularly telling in this regard: lots of commentators maintain that Turkey had the upper hand in the Statement (threatening the breaking of the deal many times), pushing the EU to set aside the thorny issue of the effective protection of human rights in the country, an utmost priority in EU relations with third states, at least on rhetoric (Collet 2016). To notice for this work, not only the EU would turn a blind eye to Turkey's treatment of its own citizens for the sake of the deal tenure, but would also subject migrants and asylum seekers returned or prevented to depart to the risk of such treatment. The EU's reference to a 'sufficient' degree of protection furnished by these third countries, as set in the proposed legislation, rules out the necessity for a level of protection comparable to the one in the EU but also in conformity with international Conventions. Instead, it seems to accept a significantly lower system of safeguards for protection seekers. According to ECRE (2016e: 2) 'sufficient protection' is an insufficient legal basis to deflect responsibility for refugee protection'. The reports of many Organisations on protection conditions in Turkey seem to confirm this belief (see for example, Gogou 2017).

\footnotetext{
${ }^{10}$ The necessity has in fact been underlined to envisage the cooperation of the Agency with countryspecific experts, the judiciary, NGOs and the UNHCR for the analysis of country of origin information, given the Agency's contribution on single applications examination (ECRE 2016f, p. 24).

${ }^{11}$ The EU-Turkey Statement of March 2016 specifically relied on these concepts (i.e. the definition of Turkey as a 'first country of asylum' and 'safe third country') as the legal bases upon which asylum seekers could be returned from the Greek islands to Turkey.
} 
Again, this seems to advance a conception of justice attentive primarily not to endanger states' interests, while support for a conception of impartiality is drifted apart if not neglected. Furthermore, if deals are made with third countries lacking effective institutional and legal provisions on migrants and asylum seekers, one may even question EU's role in potential domination practices against these persons.

\section{Whose protection?}

A second set of observations should be made with respect to the understanding of 'asylum protection' that these proposals for reform seem to suggest. This assessment is not trivial, given that, as seen above, the Union has often described itself as a protection space, as a promoter of human rights in general, and as a protector of those of vulnerable categories and minorities; and it has deeply committed to the rule of law and to internal and international obligations. It is not trivial also because the European Union has elevated the 'right to asylum' to a fundamental right in its Charter of Fundamental Rights (Art. 18). It has endorsed a conception of international protection well beyond Geneva standards; and it has called upon its Court of Justice to monitor Member States' practices (sometimes redressing injustices and covering loopholes in its own legislation). Hence, the EU is rightly expected to support a quite extensive meaning of international protection with respect to other actors and to serve as an example in broader fora of discussion on the global governance of asylum.

However, this does not seem to be the case. In the recent proposals for reform of the asylum system, the understanding of protection turns out to be significantly spoiled. It seems a) to have been affected by the increasing connection between the phenomenon of asylum and that of irregular immigration control; b) to have become a 'time-dependent' right; c) to have been associated with an increasing amount of obligations upon applicants and refugees; and d) to offer different rights according to the categories in which protection seekers fall. Let us consider these aspects.

\section{Asylum blurring into and serving irregular immigration control?}

Applying for asylum has become basically the only way to enter the European Union for migrants without a regular permit (regular opportunities for entry have diminished drastically in recent years everywhere in the EU). Inevitably, this has created a backlog in asylum applications which has meant increasing time and resources spent in the EU. Concurrently, it has shaped the idea that protection seeking is often an abusive practice. Expressions such as 'mixed migratory flows' or 'hybrid migratory flows', often used in EU documents, are evocative in this regard. Increasingly, therefore, asylum policies as much as migration policies have been reframed to take into due account the possibility of abusive behaviour by the irregular immigrants, not deserving protection. The increasing tie between 
the asylum and irregular immigration control policies and tools will inevitably distort the understanding of international protection as a fundamental right in the European Union.

Among the proposals for reform of the asylum system in the European Union, this change in perspective has been clearly evidenced by the (recast) proposal on the establishment of EURODAC, drafted in 2016 by the European Commission (2016f). Originally an exclusive tool for the asylum process, EURODAC could become extremely important for addressing irregular immigration, and in particular for contributing to the return of irregular immigrants. In fact, the system is expected to collect the fingerprints of not only those persons illegally crossing an external border of a Member State for determination of the responsible state under the Dublin Regulation (its original task), but also those of irregular immigrants already in the Member States. To be emphasised is that fingerprints collected could originally not be used for any purpose other than that of the proper functioning of the asylum policy. In this sense, this proposal is a clear U-turn in the EU's legislation on asylum. The need to cope with the huge number of irregular immigrants remaining 'invisible' (including unaccompanied minors), a situation 'that facilitates unauthorised secondary and subsequent movements and illegal stay within the EU' (European Commission 2016f: 2) therefore legitimises, according to the Commission, the use of an asylum instrument to serve irregular immigration control objectives. In accordance with this shift in purpose, the revision of the system envisages the possibility of fingerprinting minors aged at least six years old (previously it was 14 years). According to the Commission, storing the fingerprints of minors aged six years old would specifically recognise their vulnerability, reducing opportunities for smuggling and trafficking and increasing the likelihood that family links or links with a guardian in another Member State will soon be established (European Commission 2016f: 3). That is, according to the argument of the Commission, storing the fingerprints of minors would increase their rights and in this sense this would conform to an understanding of justice as impartiality and mutual recognition. According to others, however, it is exactly the reverse: taking the fingerprints of children would scare them while not answering the question of why those children are disappearing (Eriksson 2017).

Another consequence of the apparent overlap between different domains (asylum and irregular immigration) is the possibility to store the data collected for an extended period of time (five years) to match other databases addressing irregular immigration (European Commission 2016f: 4). Moreover, the new purpose of the system would expand the scope of data sharing with third countries for the purpose of return (ibid.), a practice that may render them highly vulnerable to their governments. The use and storage of data may run contrary to the right of privacy and data protection as enshrined in the Charter of Fundamental Rights of the EU (ECRE 2016g) and hence may contravene the EU's set of guarantees applicable to everyone. Overall, the proposed reform seems to be largely oriented towards improving the effectiveness of the fight against irregular immigration, a thorny issue for Member States that reiterates a conception of justice as non-domination, but that has poorly to do with the domain of international protection. 


\section{A deadline for the right to asylum?}

Another feature emerging quite clearly in the new package of reforms concerns 'time constraints' with respect to protection in the European Union. Indeed, attaching time limits to what is supposed to be a fundamental right (according to the EU Charter) underscores the idea that the asylum policy serves more the needs of Member States than those of protection seekers. Time constraints are articulated thus: applications for asylum should be processed quickly; and deadlines should accompany the protection system in the European Union. The first aspect is evidenced by the adoption of 'accelerated examination procedures' for certain categories of protection seekers (European Commission 2016d, Art. 40). These provisions were already present in the EU's legislation as seen above. However, in the proposal for Regulation establishing a common procedure for international protection (European Commission 2016d), they are to become mandatory for all Member States. To be noted is that the accelerated procedures can be also undertaken in the case of failure to apply in the Member State of first irregular entry under the Dublin Regulation (not possible before) (European Commission 2016d, Art. 40). The second aspect can be discerned in the attempt to set very narrow limits of time within which applicants should undergo the different phases of the asylum process and the reduction of their rights in the case of noncompliance with the time schedule (see for example European Commission 2016d, Art. 2527). Both aspects seem to be at odds with a conception of justice as impartiality: indeed, speeding up examination procedures may also be in the interest of asylum seekers, but this should not prevent the full enjoyments of their rights, such as the right to have a full assessment of their requests. Also, the imposition of deadlines and the concomitant reduction of rights seem not to recognize that because of the experiences gone through, the lack of information, and the personal difficulty in elaborating the own personal situation, some asylum seekers may have evident difficulties in respecting time-constraints.

Adding to the idea of the right to asylum as time-dependent, the proposal for a Regulation on qualifications (European Commission 2016a) stipulates constant verification of refugees' need for protection in the EU (European Commission 2016a : 4). This is not in breach of EU legislation, even though some of the provisions related to this 'verification' remain undetermined and hence open to interpretation. However, two points are worth emphasising: first, underscoring the 'temporary' nature of protection in the EU sits oddly with the objective of offering true integration opportunities for persons in need of international protection, which is instead clearly declared in the EU's documents on Integration (Ceccorulli 2017). Second, the words used by the Union make one wonder whether, in fact, the EU is retreating on its commitment (moral and legal) to offer protection to instead prioritise the reduction of asylum seekers arriving in the EU: 'The absence of checks on the continued need for protection gives the protection a de facto permanent nature, thereby creating an additional incentive for those in need of international protection to come to the EU rather than to seek refuge in other places, including in countries closer to their countries-of-origin'(European Commission 2016a: 4). The message here is clearly addressed to asylum seekers still to head for the EU, acting as a disincentive. Here again a conception of justice as non-domination 
seems to be advanced to the detriment of one as impartiality. That is, focus is on insisting on alternative (external) patterns of protection rather than on reiterating the protection rights granted by the Union.

\section{A protection to be actively and constantly deserved?}

The increasing obligations imposed on asylum seekers and refugees permeate all the proposals for reform of the asylum system in the European Union. As seen above, adherence to the 'timing' set for the asylum procedure is already a clear obligation upon protection seekers. The most telling of these obligations, though, is the one which impedes the choice of the preferred Member State, the true leitmotif of the overall package of reforms.

The new proposal for a Regulation establishing a Union Resettlement Framework (European Commission 2016g) - that is, a 'structured, harmonised and permanent' collective framework for the resettlement of persons in clear need of international protection in the European Union (European Commission 2016g: 2) - specifies the obligation of resettled protection seekers to remain in the Member State of resettlement (European Commission 2016g: 4). A similar obligation is stated in the proposal for the (recast) Dublin Regulation (European Commission 2016b), where applicants' presence and stay in the Member State of application is a requirement for the supply of effective reception conditions (Art. 5). Possible limitations to the provision of material reception outside the state assigned according to the Dublin Regulation are confirmed in the new proposal for a Directive laying down standards on reception (European Commission 2016c, Art. 17a). The proposal for Regulation on Qualification reiterates this understanding of protection by making explicit the obligation for persons entitled to international protection to remain in the state that granted protection: 'Beneficiaries of international protection shall not have the right to reside in Member States other than the one which granted protection' (European Commission 2016a, Art. 29). Another relevant provision urges asylum seekers to apply in the first country of entry and to remain in the state 'responsible' for the examination of the application, at the risk of countermeasures in the case of non-compliance (European Commission 2016b, Art. 4-5). In fact, it is specified, 'the right to apply for international protection does not encompass any choice of the applicant which Member State shall be responsible for examining the application for international protection' (European Commission 2016b, Art. 6). As a consequence of this emphasis, the 'right to information' is shifting into a duty to duly inform asylum seekers with respect to their obligations and of the consequences of non-conformity (European Commission 2016b, Art. 6). Again, the impossibility of choosing the preferred destination country does not violate a right of protection seekers; nor would the denial of free movement within the EU space (even though some 'cosmopolitan' scholars would raise more than an objection in this regard, see Carens 2013). However, failure to grant them 'a voice' will impact negatively on their subjectivity and consequently on their integration possibilities. This has already been reported as exerting huge impact on asylum seekers in terms of stress, confusion and perceived 
unfairness (Migrant Voice 2017).12 Also, one may wonder whether these obligations leave refugees with less resources to claim their rights, denouncing in this case possible domination features.

Duties and obligations are even more demanding when they impose major responsibilities on asylum seekers with respect to their asylum applications. Specifically, the new proposal for a Regulation on Qualification (European Commission 2016a) clarifies that it is the applicant's responsibility to submit all the elements available to him or her which substantiate the application for international protection (Art. 4). Moreover, the proposal for the (recast) Dublin Regulation underscores that applicants are obliged to provide the relevant elements and information regarding the responsibility determination process, respecting the time schedule set by the proposal, at the risk of no consideration being made of information unjustifiably provided afterwards (European Commission 2016b, p. 15, Art. 4). The responsibilities imposed upon protection seekers with respect to the provision of 'necessary' information may not qualify as violations of EU or international law, but they indeed testify to the failure to take into account the challenges encountered by asylum seekers ending up in the EU (ECRE 2016e). In fact, many impediments, as seen before, (among them language difficulties, lack of relevant identification documents, but also the personal experiences endured by applicants) may concur to hamper the timely and appropriate provision of information, as seen before.

Non-compliance may transform into outright punishment, as evidenced in the proposal for Directive on reception conditions in the EU, where the failure of an asylum seeker to remain in the place assigned may open the way for his/her detention (European Commission 2016c: 16); or in the proposal for the reform of the Dublin system where failure to comply with the obligations set opens the way to the 'accelerated procedure' for applications examination (European Commission 2016b, Art. 5). Or, also, when failure to remain in the state which offered protection for the duration established negatively impinges on the possible acquisition of the EU long-term resident status (European Commission 2016a: 15), and when protection seekers that have attempted to enter, have entered, or have stayed irregularly in the EU during the five years prior to resettlement are not eligible under the Union Resettlement Framework (European Commission 2016g, Art. 6). The sanctioning of asylum seekers' 'irregular' behaviour is questionable at best (ECRE 2016d). In particular, the fact that non-compliance may have effects on the asylum applications and on the asylum condition (use of an accelerated procedure, the denial of material reception) may run contrary, according to ECRE (2016g), to the same indivisible scope of the Reception Directive as applicable to all asylum seekers. The possible detention, the possible exclusion from resettlement

${ }^{12}$ The only exception to this has been the extension within the Dublin Regulation of the notion of family members to 'siblings', which specifically came as recognition that secondary movements can be better addressed by taking applicants' specific situations and exigencies into account (European Commission 2016b: 37). 
programmes ${ }^{13}$, and from the long-term resident status application, among others, are limitations to the opportunities and rights of protection seekers (an already vulnerable category), nurturing not only debates on the conformity of these measures with respect to the endorsed law (widely discussed), but also, and most importantly, reflections on the meaning that international protection is gradually assuming in the EU.

\section{A 'selective" protection?}

The last consideration emerging from the package of reforms is that some asylum seekers seem to deserve more (or less) than others. The mandatory release of 'different' residence permits with respect to 'duration' to refugees and to persons entitled to subsidiary protection, for example, cannot be reasonably sustained given that 'no objective temporal difference can be established in the protection needs of the two categories of international protection beneficiaries' (ECRE 2016b: 2).14 But the impact of this 'selective' approach seems to be far greater with respect to asylum seekers still awaiting a final decision on their application.

Mandatory accelerated procedures are indeed a selection instrument and hence one discriminating among protection seekers; they are even more so specifically because of the newly introduced criterion for adopting the procedure, that is, 'when an applicant comes from a safe country of origin' (European Commission 2016d: 15). Would not this run contrary to the obligation to ascertain individual asylum claims as explicitly reiterated in EU law? Would not safe country criteria dilute the interpretation of the 'right of asylum in the EU' if asylum seekers falling in these categories do not receive proper consideration of their asylum requests (ECRE 2015)? The adoption of a common list of safe countries of origin qualifies as a pre-selection device based on the nationality criteria that would have direct legal effects on the safeguarding of rights and guarantees normally attributed to protection seekers. According to ECRE (2016e), the safe country of origin concept should be deleted because it contravenes the 1951 Refugee Convention warning not to discriminate on the basis of race, religion or country of origin. ${ }^{15}$ This blanket 'pre-selection' criterion may be deaf to the proper recognition of protection seekers' personal stories (Ceccorulli and Lucarelli 2017; ECRE 2015: 2). The establishment of pre-determined selection criteria overlooks the fact that protection needs are always 'personal'; hence, for example, it has been pointed out that migrants that left without protection claims may become in need of such protection after the sufferings endured during their journey into the EU (Crawley et al., 2015: 65).

\footnotetext{
${ }^{13}$ For a comment on the proposal for a Regulation on a Union Resettlement Framework see Caritas et al. 2016: 5 .

14 The same argument holds for the different social assistance benefits envisaged.

15 This position is not shared by the EU Agency for Fundamental Rights, which stresses that, if accompanied by fundamental rights safeguards for the persons in genuine need of international protection coming from the countries on the list, it would be a legitimate instrument with which to focus on and provide timely evaluation of protection seekers' applications (FRA 2017).
} 
A 'selective approach to human rights' runs contrary to their clear universality and may call into question the non-refoulement principle (Woollard 2017). Many protection seekers ending up in transit countries by means of the safe country concept, may see their condition become even more precarious and vulnerable because it is not backed by any clear legal framework for protection in those countries (Council of Europe 2015).

\section{Conclusion}

The field of asylum may appear to be little open to discretion from a global justice perspective, as it is rooted in certain principles, values, norms and laws that the Union has endorsed, adopted and promoted worldwide. However, the analysis undertaken has underlined that the policy of asylum in the EU has been developed and geared mainly towards the preservation of integration, with its multiple limitations and weaknesses ready to surface at the first 'disruption' of the system. This has been clearly evidenced by the tendency to propose a standardisation process aimed at not disappointing less 'protective' national systems; to apply and confirm EU law even when this risks nullifying the principle of solidarity; and to off-load the failures of a fragmented and incomplete asylum system onto third states. As noted, 'asylum systems, comprising rules, procedures, and the necessary administrative resources to put them to practice, very often shift from substantive protection enquiries to distribution-related ones; focus is placed on 'where' rather than 'who' gets protection' (ECRE 2016a: 6). Indeed, this is in stark contrast to the EU's planned objective to strengthen 'Europe's duty to protect', as underlined in the Agenda on Migration of 2015 (European Commission 2015a). In this sense, the European Union seem to significantly conform to the justice conception of 'non-domination', by giving centrality to sovereign prerogatives in the asylum domain. However, there is a possibility that this conception is challenged, and dominance traits come to the surface. The advancement of such a conception of justice seems to clash with conceptions of justice as impartiality and mutual recognition, attesting EU's back-pedalling from previous commitment on the support of human rights. The words of the Commission are telling in this regard: 'while fully respecting fundamental rights and international norms, the Commission will carefully examine the need to adapt the level of rights in order to reduce both undue pull factors and secondary movements' (European Commission 2016h: 10).

The puzzle is not only that in the field of asylum governance the EU may advance a principle that does not match its human rights rhetoric, but also that this may backfire on its very nature and distinctiveness. 


\section{References}

Asylum Information Database (AIDA) (2017) 'The Dublin System in 2016. Key Figures from Selected European Countries, European Council on Refugees and Exiles (ECRE). Available at: https://s3.amazonaws.com/ecre/wpcontent/uploads/2017/03/27170638/AIDA 2016Update Dublin.pdf [Accessed 23 February 2018].

Balleix, C. (2017) 'Dublin et Schengen: regagner la confiance et renforcer la solidarité entre les états membres de l'Union europeénne', Question d'Europe policy Paper n ${ }^{\circ} 434$, Fondation Robert Schuman, 15 May. Available at: https://www.robert-schuman.eu/ fr/questions-d-europe/0434-dublin-et-schengen-regagner-la-confiance-etrenforcer-la-solidarite-entre-les-etats-membres-de [Accessed 23 February 2018].

Carens, J. H. (2013) The Ethics of Immigration, Oxford: Oxford University Press.

Caritas Europa, Churches' Commission for Migrants in Europe (CCME), European Council for Refugees and Exiles (ECRE), International Catholic Migration Commission (ICMC Europe), International Rescue Committee (IRC), Red Cross EU office (2016) 'European Commission Proposal for a Regulation Establishing a Union Resettlement Framework and Amending Regulation (EU) No 516/2014 of the European Parliament and the Council COM (2016) 468, 13 July 2016' Joint Paper, 14 November. Available at: https://www.ecre.org/wp-content/uploads/2016/11/NGOjoint-comments-resettlement-141116.pdf [Accessed 23 February 2018].

Ceccorulli, M. (2017) 'EU Terms, Definitions and Concepts on Migration', in E. Fassi and S. Lucarelli (eds) The European Migration System and Global Justice: a First Appraisal, GLOBUS Report 1/17, Oslo: ARENA.

Ceccorulli, M. and Lucarelli, S. (2017) 'EU Migration Terms, Definitions and Concepts: Perspectives of Justice', in E. Fassi and S. Lucarelli (eds) The European Migration System and Global Justice: a First Appraisal, GLOBUS Report 1/17, Oslo: ARENA.

Collet, E. (2016) 'The Paradox of the EU-Turkey Refugee Deal', Migration Policy Institute. Available at: https://www.migrationpolicy.org/news/paradox-euturkey-refugee-deal [Accessed 26 February 2018].

Council of Europe (2015) 'Countries of Transit: Meeting New Migration and Asylum Challenges', Resolution 2073. Available at: http://semantic-pace.net/tools/ pdf.aspx?doc=aHRocDovL2Fzc2VtYmx5LmNvZS5pbnQvbncveG1sL1hSZWYvW DJILURXLWV4dHIuYXNwP2ZpbGVpZDoyMjAxNyZsYW5nPUVO\&xsl=aHRo cDovL3NlbWFudGljcGFjZS5uZXQvWHNsdC9QZGYvWFJlZi1XRC1BVC1YTUw yUERGLnhzbA==\&xsltparams=ZmlsZWlkPTIyMDE3 [Accessed 26 February 2018].

Crawley, H., Düvell, F., Jones, K., McMahon, S. and Sigona, N. (2016) 'Destination Europe? Understanding the Dynamics and Drivers of Mediterranean Migration in 2015', MEDMIG Final Report. Available at: http://www.medmig.info/wpcontent/uploads/2016/12/research-brief-destination-europe.pdf [Accessed 26 February 2018]. 
Del Gaudio, E., Finlay, G., Heikkilä, M., Konstantis, S., Hegde, V.G., Morondo, D., Mustaniemi-Laakso, M. and Nagore Casas, M. (2016) 'The Protection of Vulnerable Individuals in the Context of EU Policies on Border Checks, Asylum and Immigration', FRAME. Available at: http://www.fp7-frame.eu/wpcontent/uploads/2016/o8/Deliverable-11.3.pdf [Accessed 26 February 2018].

Den Heijer, M., Rijpma, J. and Spijkerboer T. (2016) 'Coercion, Prohibition, and Great Expectations: The Continuing Failure of the Common European Asylum System', Common Market Law Review 53 (3): 607-642.

ECRE (2015) ECRE Comments on the Proposal for a Regulation of the European Parliament and of the Council establishing an EU common list of safe countries of origin and amending the recast Asylum Procedures Directive COM(2015) 452, October 2015. Available at: https://www.ecre.org/wp-content/uploads/ 2016/07/ECRE-Comments-on-the-Commission-Proposal-for-an-EU-commonlist-of-safe-countries-of-origin Oct-2015.pdf [Accessed 26 February 2018].

ECRE (2016a) Admissibility, responsibility and safety in European asylum procedures, AIDA Asylum Information Database. Available at: https://www.ecre.org/wp-content/uploads/2016/o9/ECRE-AIDA-

Admissibility-responsibility-and-safety-in-European-asylum-procedures.pdf

ECRE (2016b) ECRE Comments on the Commission Proposal for a Qualification Regulation, COM (2016) 466, November. Available at: https://www.ecre.org/ ecre-comments-on-the-proposal-for-a-qualification-regulation/ [Accessed 26 February 2018].

ECRE (2016c) ECRE Memorandum to the European Council Meeting 17 - 18 March 2016.Time to Save the Right to Asylum, 11 March. Available at: https://www.ecre.org/time-to-save-the-right-to-asylum-ecre-memorandum-tothe-european-council-meeting-17-18-march-2016/[Accessed 26 February 2018].

ECRE (2016d) ECRE Comments on the Commission Proposal for a Dublin IV Regulation COM (2016) 270, October 2016. Available at: https://www.ecre.org/wp-content/uploads/2016/10/ECRE-Comments-DublinIV.pdf[Accessed 26 February 2018].

ECRE (2016e) ECRE Comments on the Commission Proposal for an Asylum Procedures Regulation COM (2016) 467, November. Available at: https://www.ecre.org/ecre-comments-on-the-proposal-for-an-asylumprocedures-regulation/ [Accessed 26 February 2018].

ECRE (2016f) ECRE Comments on the Commission Proposal for a Regulation on the European Union Agency for Asylum and repealing Regulation (EU) No 439/2010, $\operatorname{COM}(2016)$ 271, July 2016. Available at: https://www.ecre.org/wpcontent/uploads/2016/o7/ECRE-Comments-EU-Asylum-Agency July-2016final 2.pdf [Accessed 26 February 2018].

ECRE (2016g) ECRE Comments on the Commission Proposal to recast the Reception Conditions Directive, COM (2016) 465, October 2016. Available at: https://www.ecre.org/wp-content/uploads/2016/10/ECRE-CommentsRCD.pdf [Accessed 26 February 2018]. 
Egan, S., Finlay, G., Heikkilä, M., Heschl, L.M., Lewis, T., Mustaniemi -Laakso, M., Planitzer, J., Salomon, S. and Sax, H. (2015) 'Critically Assessing Human Rights Integration in AFSJ Policies', FRAME, 31 October. http://www.fp7-frame.eu/ frame-reps-11-2/[Accessed 26 February 2018].

Eriksen, E.O (2016) 'Three Conceptions of Global Political Justice', GLOBUS Research Papers, 1/2016. Available at: http://www.globus.uio.no/ publications/globus-research-papers/2016/2016-01-globus-research-papereriksen.html [Accessed 26 February 2018].

Eriksen, E. O (2017) 'Structural Injustice and Solidarity. The Case of the Eurozone Crisis', ARENA Working Paper Series, 4/2017. Oslo: ARENA.

Eriksson, A. (2017) 'EU to Find Missing Migrant Children with Fingerprinting', EUObserver, Brussels, 16 March. Available at: https://euobserver.com/ migration/137249 [Accessed 26 February 2018].

European Commission (2000) Towards a common asylum procedure and a uniform status, valid throughout the Union, for persons granted asylum, COM (2000) 755 final, Brussels, 22 November.

European Commission (2003) On the common asylum policy and the Agenda for Protection, COM (2003)152 final, Brussels, 26 March.

European Commission (2013) Report from the Commission to the European Parliament and the Council on the application of directive 2004/83/EC of 29 April 2004 on minimum standards for the qualification and status of third country nationals or stateless persons as refugees or as persons who otherwise need international protection and the content of the protection.13.12.2013

European Commission (2015a) A European Agenda on Migration, COM (2015)240 final, 13 May 2015.

European Commission (2015b) Proposal for a regulation of the European Parliament and of the Council establishing an EU common list of safe countries of origin for the purposes of Directive 2013/32/EU of the European Parliament and of the Council on common procedures for granting and withdrawing international protection, and amending Directive 2013/32/EU, COM (2015) 452, 9 September.

European Commission (2016a) Proposal for a Regulation of the European Parliament and of the Council on standards for the qualification of third-country nationals or stateless persons as beneficiaries of international protection, for a uniform status for refugees or for persons eligible for subsidiary protection and for the content of the protection granted and amending Council Directive 2003/109/EC of 25 November 2003 concerning the status of third-country nationals who are longterm residents, $\operatorname{COM(2016)~466,~Brussels,~} 13$ July.

European Commission (2016b) Proposal for a Regulation of the European Parliament and of the Council establishing the criteria and mechanisms for determining the Member State responsible for examining an application for international protection lodged in one of the Member States by a third-country national or a stateless person (recast), COM (2016) 270, Brussels, 4 May.

European Commission (2016c) Proposal for a Directive of the European Parliament and of the Council laying down standards for the reception of applicants for international protection (recast), COM (2016) 465, Brussels, 13 July. 
European Commission (2016d) Proposal for a Regulation of the European Parliament and of the Council establishing a common procedure for international protection in the Union and repealing Directive 2013/32/EU, COM(2016) 467, Brussels, 13 July.

European Commission (2016e) Proposal for a Regulation of the European Parliament and of the Council on the European Union Agency for Asylum and repealing Regulation (EU) No 439/2010, COM(2016) 271, Brussels, 4 May.

European Commission (2016f) Proposal for a Regulation of the European Parliament and of the Council on the establishment of 'Eurodac' for the comparison of fingerprints for the effective application of [Regulation (EU) No 604/2013 establishing the criteria and mechanisms for determining the Member State responsible for examining an application for international protection lodged in one of the Member States by a third-country national or a stateless person], for identifying an illegally staying third-country national or stateless person and on requests for the comparison with Eurodac data by Member States' law enforcement authorities and Europol for law enforcement purposes (recast), $\operatorname{COM}(2016)$ 272, Brussels, 4 May.

European Commission (2016g) Proposal for a Regulation of the European Parliament and of the Council establishing a Union Resettlement Framework and amending Regulation (EU) No 516/2014 of the European Parliament and the Council, $\operatorname{COM}(2016)$ 468, Brussels, 13 July.

European Commission (2016h) Towards a reform of the Common European Asylum System, COM (2016) 197 final, 6 April 2016.

European Council (2005) On minimum standards on procedures in Member States for granting and withdrawing refugee status, Council Directive 2005/85/EC, 1 December.

European Parliament and European Council (2010) Regulation establishing a European Asylum Support Office, Regulation nº439/2010, 19 May.

European Parliament and Council (2011) Directive 2011/95/EU of the European Parliament and of the Council on standards for the qualification of third-country nationals or stateless persons as beneficiaries of international protection, for a uniform status for refugees or for persons eligible for subsidiary protection, and for the content of the protection granted, 13 December 2011.

European Parliament (2017) 'Reform of the EU asylum rules - creating a new Dublin system that works', Background, 6 March. Available at: http://www.europarl.europa.eu/pdfs/news/expert/background/20170306BKG 65314/20170306BKG65314 en.pdf [Accessed 26 February 2018].

European Union Agency for Fundamental Rights (FRA) (2016) 'The Impact of the Proposal for a Revised Eurodac Regulation on Fundamental Rights', FRA Opinion 2/2016, Vienna. Available at: http://fra.europa.eu/en/opinion/2017/ impact-proposal-revised-eurodac-regulation-fundamental-rights [Accessed 26 February 2018]. 
European Union Agency for Fundamental Rights (FRA) (2017) 'Opinion of the European Union Agency for Fundamental Rights Concerning an EU Common List of Safe Countries of Origin', FRA Opinion 1/2016, Vienna. Available at: http://fra.europa.eu/en/opinion/2016/fra-opinion-concerning-eu-commonlist-safe-countries-origin[Accessed 26 February 2018].

Fassi, E. and Lucarelli, S. (eds) (2017) 'The European Migration System and Global Justice: a First Appraisal', GLOBUS Report 1/17.

Gibney, M. (2004) The Ethics and Politics of Asylum, Cambridge: Cambridge University Press.

Gibney, M. (2015) 'Refugees and Justice between States', European Journal of Political Theory 14(4), 448-463.

Gogou, K. (2017) 'The EU-Turkey Deal: Europe's Year of Shame', Amnesty International, 20 March 2017. Available at: https://www.amnesty.org/en/latest/ news/2017/03/the-eu-turkey-deal-europes-year-of-shame/[Accessed 26 February 2018].

Grandi, F. (2016) 'Protecting Refugees in Europe and beyond: Can the EU Rise to the Challenge?', Speech at the European Policy Centre, Brussels, 5 December 2016. Available at: http://www.unhcr.org/admin/hcspeeches/58456ec34/protectingrefugees-europe-beyond-eu-rise-challenge.html [Accessed 26 February 2018].

Guild, E., Costello, C., Garlik, M. and Moreno-Lax, V. (2015) 'Enhancing the Common European Asylum System and Alternatives to Dublin', Directorate general for internal policies policy department C: Citizens' rights and constitutional affairs civil liberties, justice and home affairs, European Parliament. Available at: http://www.epgencms.europarl.europa.eu/cmsdata/upload/983a50a5-69d648b1-aobd-2b34ccedge36/Sessions 1 and 2 Study European Asylum System and Alternatives to Dublin.pdf [Accessed 26 February 2018].

Migrant Voice (2017) 'Roads to Nowhere. Case Studies of Europe's Dublin Regulation and its Impacts', March 2017. Available at: http://www.migrantvoice.org/work/ national/our-report-on-the-impact-150317151602 [Accessed 26 February 2018].

Mikalsen, K.K. (2017) 'Equal Sovereignty: On the Conditions of Global Political Justice', GLOBUS Research Papers, 3/2017, Oslo: ARENA.

Miller, D. (2015) 'Justice in Immigration', European Journal of Political Theory 14(4), 391-408.

Miller, D. (2016) Strangers in Our Midst. The Political Philosophy of Immigration, Cambridge and London: Harvard University Press.

Pascouau, Y. (2017) 'La Déclaration de Rome du 25 mars 2017 et la migration: des reculs inquiétants ?', Points de vue, EuropeanMigrationLaw.eu. Available at: https://alliance-europa.eu/fr/post/la-declaration-de-rome-du-25-mars-2017et-la-migration-des-reculs-inquietants/[Accessed 26 February 2018].

Pastore, F. (2017) Beyond the Migration and Asylum Crisis. Options and Lessons for Europe, Aspen Italia Views, Aspen Institute Italia-Treccani.

Schlein, E. (2017) 'What the European Union is experiencing at the moment is a lack of trust', Asylum corner, 20 February 2017. 
Sjursen, H. (2017) 'Global Justice and Foreign Policy: The Case of the European Union', GLOBUS Research Papers, 2/2017.

Triandafyllidou, A. (2017) 'Big Changes in EU Migration Governance', EUObserver, Brussels, 17 March 2017. Available at: https://euobserver.com/opinion/137215 [Accessed 26 February 2018].

Woollard, C. (2017) 'Weekly Editorial: Once we were Tearing down Walls - Now we are Building them', 3 March 2017. Available at: https://www.ecre.org/weeklyeditorial-once-we-were-tearing-down-walls-now-we-are-building-them/ [Accessed 26 February 2018]. 
$4 / 2018$

Michela Ceccorulli

On Protection and Justice:

the Proposals for Reform of the

Common European Asylum System

$3 / 2018$

Ben Tonra

The (In) Justices of Peacekeeping:

EUFOR Tchad/RCA

2/2018

Nikola Tomić and Ben Tonra

The Pursuit of Justice Through EU

Security Strategies

Sisyphus Redux?

$1 / 2018$

Alexa Zellentin

Different Angles on Climate Justice Insights from Non-domination and Mutual Recognition

\section{$6 / 2017$}

Mai'a K. Davis Cross

Europe's Foreign Policy and the Nature of Secrecy

$5 / 2017$

Bettina Ahrens

The Solidarisation of International

Society:

The EU in the Global Climate Change Regime
$4 / 2017$

Mai'a K. Davis Cross

EU Institutions and the Drive for Peace The Power of Ideas

$3 / 2017$

Kjartan Koch Mikalsen

Equal Sovereignty

On the Conditions of Global Political Justice

2/2017

Helene Sjursen

Global Justice and Foreign Policy

The Case of the European Union

$1 / 2017$

Franziskus von Lucke

O Justice, Where Art Thou?

Developing a New Take on Climate Justice

$1 / 2016$

Erik O. Eriksen

Three Conceptions of Global Political Justice 


\section{GLOBUS Research Papers}

The GLOBUS Research Papers are pre-print manuscripts on the EU's contribution to global justice as well as the wider question of Global Political Justice. The series is multidisciplinary, with a particular emphasis on the fields of international relations, political science, political theory, sociology and law.

\section{Reconsidering European Contributions to Global Justice - GLOBUS}

GLOBUS is a research project that critically examines the European Union's contribution to global justice. Challenges to global justice are multifaceted and what is just is contested. Combining normative and empirical research GLOBUS explores underlying political and structural obstacles to justice. Analyses of the EU's positions and policies are combined with in-depth studies of non-European perspectives on the practices of the EU. Particular attention is paid to the fields of migration, trade and development, cooperation and conflict, as well as climate change. GLOBUS' team of researchers covers the disciplines of politics, international relations, law, economics, sociology and political theory. The project is coordinated by ARENA Centre for European Studies at the University of Oslo and has partners in Brazil, China, Germany, India, Ireland, Italy and South Africa. It is funded by the Horizon 2020 Programme of the European Union for the period 1.6.2016 - 31.5.2020.

\section{Series Editor}

Helene Sjursen, ARENA Centre for European Studies, University of Oslo GLOBUS Coordinator

\section{Editorial Board}

Thomas Diez

Erik O. Eriksen

Sonia Lucarelli Pundy Pillay

Ben Tonra
Institute of Political Science, University of Tübingen ARENA Centre for European Studies, University of Oslo Department of Political and Social Sciences, University of Bologna Wits School of Governance, University of Witwatersrand School of Politics and International Relations, University College Dublin 